\title{
Does Broadband Access Impact Migration in America? Examining Differences between Rural and Urban Areas
}

\begin{abstract}
Phumsith Mahasuweerachai $^{*}$ Brian E. Whitacre, and Dave W. Shideler ${ }^{* *}$
ABSTRACT: Using U.S. county-level population between 2000 and 2006 with two sets of broadband data (Cable and DSL) from the year 2000, we apply several econometric models to test whether the early existence of broadband access significantly affects migration. We find mild support for broadband access impacting net migration in urban areas. In contrast to anecdotal evidence, we find that rural counties with a single type of broadband did not experience a significant in-migration, suggesting that broadband access many not help solve out-migration problems. Only rural counties with both Cable and DSL access saw significant inmigration relative to similar counties without broadband.
\end{abstract}

Keywords: Broadband, Migration, Rural

JEL Classification Codes: O33, O15, R15

\section{INTRODUCTION}

According to neoclassical economics, geographic differences in the supply of and demand for labor are a primary cause of population migration (Todaro and Maruszko, 1987). People who live in labor-surplus areas, which usually have lower wages, tend to migrate to labor-scarce areas with higher wages. Generally, labor-scarce areas have relatively higher economic growth with more industries and greater manufacturing concentration than do laborsurplus areas. In a neoclassical world, these differences in supply and demand induce migration, since areas with high economic growth tend to experience in-migration (Van Den Berg, 2001).

During the last 30 years or so, the traditional neoclassical view of the migration theory was altered. Concepts entered focusing on the idea that people not only consider economic activity factors but also the infrastructure and amenity factors that can improve their quality of life (Greenwood, 1985). Few people made relocation decisions without considering elements such as public schools, hospitals, transportation availability, and general quality of life. Literature on this topic consistently demonstrated that communities with a higher quantity and quality of infrastructure and amenities obtained increases in population, mostly from inmigration, while communities with lower levels of infrastructure and amenities tended to lose population (e.g., Aschauer, 1989; Gramlich, 1994; Deller et al., 2001).

Broadband and high-speed Internet access is a relatively new addition to the spectrum of infrastructure services a community can offer. ${ }^{1}$ Since its introduction in the late 1990s, broadband has been widely touted as an instrument to benefit a wide cross-section of the

\footnotetext{
* Mahasuweerachai is a Lecturer in the Department of Economics, Khon Kaen University, Thailand. ${ }^{* *}$ Brian E. Whitacre and Dave W. Shideler are both Assistant Professors \& Extension Economists at Oklahoma State University, Stillwater, OK 74075 Contact author: Mr. Phusmith Mahasuweerachai, Department of Economics, Khon Kaen University, Khon Kaen, Thailand 40002. E-mail: $\underline{\text { mchit@kku.ac.th }}$

1 Broadband access, also called high-speed access or advanced service, has traditionally been defined by the Federal Communications Commission as 200 Kilobits per second (Kbps) (or 200,000 bits per second) of data throughput in at least one direction. In 2008, however, this definition was altered to include tiered levels of service. These tiers range from $1^{\text {st }}$ generation data (200 Kbps-768 Kbps) and Broadband Tier 1 (768 Kbps to $1.5 \mathrm{Mbps}$ ) up to Broadband Tier 7 (greater than $100 \mathrm{Mbps}$ ) (Federal Communications Commission, 2008).

C Southern Regional Science Association 2011.

ISSN 1553-089

SRSA, 1601 University Avenue, PO Box 6025, Morgantown, West Virginia 26506-6025, USA.
} 
economy and society in general (Whitacre and Mahasuweerachai, 2008). The U.S. Bureau of Economic Analysis (2003) estimates that for each \$1 invested in broadband, the economy benefits nearly $\$ 3$. Other recent studies on broadband find that its presence increases industrial effectiveness and economic growth in certain sectors of the economy (Lehr et al., 2005; Ford and Koutsky, 2005; Shideler, Badasyan and Taylor, 2007). Moreover, broadband access has the potential to increase the quality of life through enhanced education, improved health care, instant connection across the country and around the globe, e-government, and employment generation (Warren, 2007; Intelligent Community Forum, 2008). Such positive impacts of broadband access on a society could improve the quality of life for its residents. Hence, the availability of broadband access would appear to represent a wave of infrastructure that likely plays a role in people's location decisions.

Population loss due to out-migration is a concern for many rural and remote areas in the U.S. because of its implications for a typical rural economy. Population loss can lead to reductions in tax revenue, potential loss of industries and job positions, and a decline in property values, all of which would seriously hurt a community's economy (Adelaja, Hailu, and Abdulla, 2008). In addition, population loss would increase the cost per capita for public services such as health care and school services, which would result in difficulties in providing these public services to the population (National Center for Frontier Communities, 2000).

Some anecdotal studies suggest that broadband access might stem the current problem of population decline in these areas (McGranahan and Beale, 2002; Korver, 2008). Wolff (2008) also finds that areas with positive net migration usually have broadband access or are located close to areas with broadband access. Besides having a direct impact on the location decision, broadband access may also provide an indirect impact on migration. Stenberg et al. (2009) find that jobs and private earnings grow faster in areas with early access to broadband, some obvious fairly evidence that it affects location decision. While many rural areas lag behind their urban counterparts in the availability of broadband, those areas fortunate enough to offer this type of infrastructure might have an advantage in attracting residents. However, to our knowledge, no empirical work has yet surfaced on this topic.

This paper attempts to answer the question of whether or not areas, especially rural ones, with access to broadband infrastructure relatively early on (by the year 2000) had higher levels of population growth from in-migration than those without it. We attempt to answer the question in two distinct ways: (1) regression analysis on migration over the period 2000-2006 and (2) average treatment effects. Various specifications are explored (including spatial econometric models) and results from the two methods are compared in an effort to make a concise statement about the impact that broadband access has had on migration. These results will be of interest to individuals involved in community development, given the relationship between migration and economic growth (Deller et al., 2001).

\section{APPROACH}

In order to make stronger statements about the impact of broadband on migration, both regression analysis and the average treatment effects method are employed. We develop a model to explain the factors that cause migration in the U.S. This model dictates the econometric framework that should help explain the role of broadband infrastructure in the migration decision. 


\subsection{Spatial Regression Model}

Suppose that the expected utility of a migrant to migrate to county $j$ can be defined as

(1) $U_{j}\left(Y_{j}, \mathbf{i}_{j}, C_{j}, \mathbf{q}_{j}\right)$

where $Y_{j}$ is the expected income that a migrant expects to earn in county $j$; $\mathbf{i}_{j}$ is the vector of infrastructure available in county $j ; C_{j}$ is cost of living in county $j$; and $\mathbf{q}_{j}$ is a vector representing the quality of life in county $j$. A migrant will migrate to the county that maximizes his/her expected utility. Applying the migration model developed by Treyz, Rickman and Hunt (1993) and Dust, Orazem and Wohlgemuth (2008) provides a reference utility that reflects the expected utility across all possible locations, denoted by $\bar{U}$. Whether or not an individual will move to county $j$ is dependent upon the difference between the utility received from moving to county $j$ and the reference utility. If the utility received from moving to county $j$ is higher than the reference utility, this individual will move to county $j$; however, if the utility received from moving to county $j$ is less than the reference utility, an individual will stay where he/she is or move to another county that maximizes his/her utility. This relation is represented by:

(2) $\Delta P_{j}=f\left(U_{j}-\bar{U}\right)$

where $\Delta P_{j}$ is the population change for county $j$, indicating net migration, and $f(\cdot)$ is the function aggregating migrants' decisions to move into county $j .^{2}$

To operationalize the model for empirical work, we specify the elements of $Y_{j}, \mathbf{i}_{j}, C_{j}$, and $\mathbf{q}_{j}$. We proxy expected wages in county $j$ using the median county income, since wage data for each sector in each county are not available. In addition, we include measures of a county's industrial composition (percent employment by industry) and employment level to proxy for the potential demand for labor in county $j$, which are all components of expected wage. We expect higher wages and employment levels to induce in-migration, while the industrial composition variables control for the relative labor-intensity of local firms.

Migrants also consider the cost of living in each county when they make their location decision. We use the average housing value in each county as the proxy for this variable, $C_{j}$. A lower cost of living should increase one's expected utility in a location; therefore, lower housing values are hypothesized to increase in-migration. Moreover, a rural dummy variable, $R_{j}$, is included to capture the difference in migration patterns between rural and urban areas. ${ }^{3}$ Previous studies indicated that the quality of life, $\mathbf{q}_{j}$, is also an important factor considered by people before making the decision to settle in a particular area. Per capita crime rate, per capita social security benefit, poverty rate, and a natural amenities index are used to represent the level of quality of life in each county.

The vector of infrastructure, $\mathbf{i}_{j}$, includes per capita local government expenditures and broadband access. The relationship between local government expenditures and migration is

\footnotetext{
2 The reference utility of each individual is unobservable. However, we can observe the difference between expected utility and reference utility by examining a county's characteristics and migration pattern.

${ }^{3}$ Using the Office of Management and Budget (OMB)'s Standards for Defining Metropolitan and Micropolitan Statistical Areas (Federal Register Notice 65 FR 82228-82238, December 27, 2000), we define counties that are not designated as metropolitan as non-metropolitan, and we refer to these non-metropolitan counties as rural.

${ }^{4}$ We use the Economic Research Service (ERS) natural amenities index, which is calculated using four measures of climate, topography, and the proportion of county area classified as water (lakes, ponds, and oceans) (McGranahan, 1999). The amenities index is ranked from 1 to 7 , with 7 being the highest.
} 
indeterminate. Because a migrant would prefer to live in areas with more extensive government support, areas with high per capita local government expenditures may be more likely to attract migrants. However, high government expenditure is typically associated with high taxes, which may decrease the likelihood of migration. For broadband infrastructure, we create a dummy variable to represent the availability of broadband access in the year 2000. The dummy variable denotes areas with at least Cable access (provided by the cable company) or Digital Subscriber Line (DSL) access (provided by the phone company) available as equal to one, and zero otherwise.

Putting these variables into the expected utility function of a migrant, and specifying the utility function in the following form, yields

(3) $U_{j}=\beta_{Y} \ln \left(Y_{j}\right)+\sum_{l=1}^{k} \beta_{l}\left(\frac{E_{l j}}{E_{j}}\right)+\beta_{m} \ln \left(M_{j}\right)+\boldsymbol{\beta}_{i}\left(\mathbf{i}_{j}\right)+\beta_{c} \ln \left(C_{j}\right)+\boldsymbol{\beta}_{q}\left(\mathbf{q}_{j}\right)$

By substituting (3) into (2), we get the empirical model as

(4) $\Delta P_{j}=\beta_{0}+\beta_{Y} \ln \left(Y_{j}\right)+\sum_{l=1}^{k} \beta_{l}\left(\frac{E_{l j}}{E_{j}}\right)+\beta_{m} \ln \left(M_{j}\right)+\beta_{c} \ln \left(C_{j}\right)+\boldsymbol{\beta}_{q}\left(\mathbf{q}_{j}\right)+\beta_{G}\left(G_{j}\right)$

$$
+\beta_{b b}\left(B B_{j}\right)+\beta_{r}\left(R_{j}\right)+\varepsilon_{j}
$$

Median county income, $Y_{j}$, industrial share in employment, $E_{l j} / E_{j}$, (where $l$ is a particular industry) and employment level, $M_{j}$, are all components of the expected wage. For industrial share in employment, the industrial sectors used are agriculture, construction, manufacturing, wholesale, retail, finance, and public administration. ${ }^{5} C_{j}$ is the average house value in county $j . G_{j}$ is the per capita local government expenditure. $B B_{j}$ is the broadband dummy variable, and $R_{j}$ is the rural dummy for this specification.

An additional consideration is that the pattern of migration and population growth may extend beyond a single county. We plot those counties which experience positive in-migration in Figure 1 and find that they are clustered; even more interesting is the clustering that emerges when one categorizes these counties by broadband availability. The clustering pattern in Figure 1 is not surprising. Boarnet (1994) and Boarnet, Chalermpong, and Geho (2005) document the spatial interdependence of migration. Johnson (2006) specifically notes that population growth rates were higher for rural counties adjacent to urban ones than they were for non-adjacent rural counties during the 1990s. This suggests clustering exists around metropolitan counties. Renkow and Hoover (2000) explain this de-concentration of population as a shift in household location preferences that favors positive locational amenities and the absence of crime, congestion, and other negative dis-amenities associated with urban areas. LeSage and Pace (2008) focus on the spatial dependence of origin-destination pairs in flow data: they find that the flow into a destination and the flow out of an origin depend upon the natures of the respective neighborhoods. Models that contain spatial lags for both locations dominate the results of all

\footnotetext{
${ }^{5}$ We also included other industrial shares for employment reported by the U.S. Census in the model, but they are not statistically significant.
} 
FIGURE 1. U.S. Counties with Net In-Migration, 2000-2006

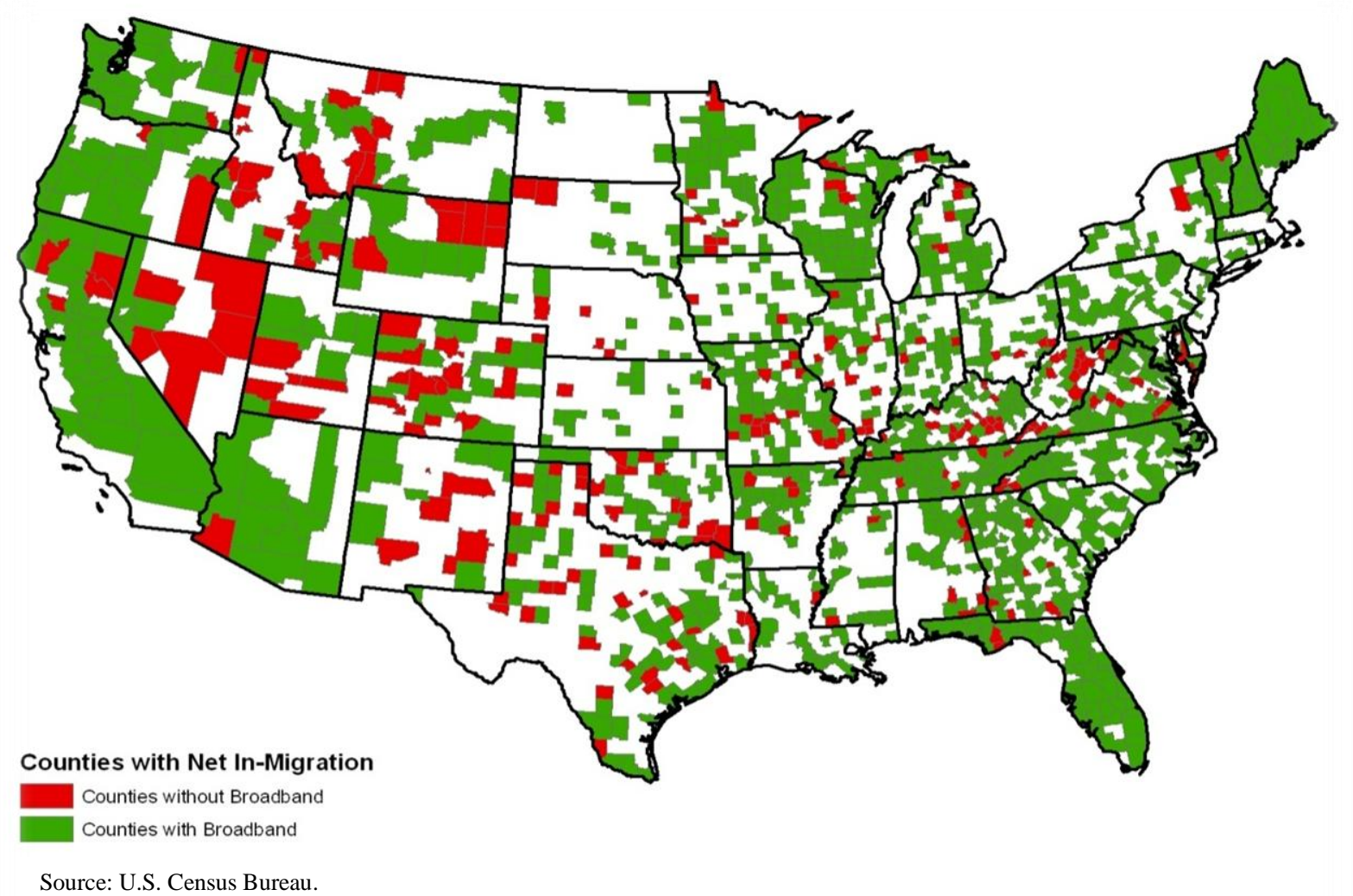

other specifications. These articles and the map of the data in question suggest the use of spatial regression techniques for our analysis.

The clustering presented in Figure 1 strongly suggests that a global population change effect exists (i.e., places with positive net migration are near places with positive net migration), and this implies the use of a spatial lag model. Still, the results and conclusions of Renkow and Hoover (2000) and Johnson (2006) suggest more localized effects of spatial dependence, especially the relationship between urban and adjacent rural counties; such dependence warrants the use of a spatial error model to capture these impacts. (See Anselin (2003) or LaSage and Pace (2009) for more details on these interpretations of the spatial models.) With the possibility of both spatial lag and spatial error effects present in our model, we apply all three model specifications (spatial lag, spatial error and general spatial) and by using Lagrange multiplier tests and other techniques we identify the model that best captures the data. The spatial lag and error models are special cases of the general spatial econometric model we represent as:

$$
\Delta P=\mathbf{x} \boldsymbol{\beta}+\rho \mathbf{W} \Delta P+u ; \quad u=\lambda \mathbf{W} u+\varepsilon ; \quad \varepsilon \sim N\left(0, \sigma_{\varepsilon}^{2} I_{n}\right)
$$

where $\mathbf{x}$ is the vector of explanatory variables shown in (4); $\mathbf{W}$ is a known spatial weight matrix ${ }^{6}$, which captures spatial dependence between each geographic area (counties in this analysis) and its neighbors; $\rho$ is a coefficient on the spatially lagged dependent variable (if $\rho=0$, then the model is a spatial error model); and $\lambda$ is a coefficient on the spatially correlated errors (if $\lambda=0$, then the

\footnotetext{
${ }^{6}$ The weight matrix was constructed using the Delaunay triangulation algorithm in MATLAB from latitude and longitude coordinates of the geographic centroid for each county.
} 
model is a spatial lag model). Lagrange multiplier (LM) tests as developed by Anselin (1988) are used to determine which spatial model is most appropriate for our analysis. If broadband access does affect migration decisions, we should expect to see a positive and statistically significant broadband coefficient estimate, after controlling for all other variables in the specification.

\subsection{Treatment Effects}

Even though regression analysis can verify whether broadband is correlated with the migration, it cannot establish causation. In addition, regression imposes greater restrictions upon the analysis, which may impact the conclusions drawn from its results. Matching techniques, on the other hand, could avoid these problems. They are not model-based and hence do not introduce restrictive assumptions.

To measure the effect of broadband on migration, we are interested in the difference in net migration rates between areas with and without broadband. This is known as the "treatment effect" because those areas with broadband are considered to have been "treated." Let $\Delta P_{j 1}$ and $\Delta P_{j 0}$ be the migration rate of the areas with and without broadband, respectively. The average treatment effect on treated (ATET) can be represented as:

(6) $A T E T=E\left(\Delta P_{j 1} \mid T_{j}=1\right)-E\left(\Delta P_{j 0} \mid T_{j}=1\right)$

where $T_{j}$ equals 1 for areas with broadband (treated) and 0 for areas without broadband (nontreated). However, we can only observe either $\Delta P_{j 1}$ or $\Delta P_{j 0}$ for a particular area, but not both, since each county will either have or lack broadband access. In other words, there is selfselection into the treatment group (Wooldridge, 2002). Typically, this would cause biased estimates of the broadband effect. To yield unbiased estimates of broadband's impact, an assumption of "conditional independence" or "exogeneity" is applied (Imbens, 2004). This assumption implies that there are no unobservable differences between areas with broadband (treated) and areas without broadband (non-treated) after conditioning on observable characteristics. Based on this assumption, the migration rate from areas without broadband could represent what similar areas with broadband would have experienced if they did not have broadband (potential outcome). Hence, to solve the problem of missing data, we have to "match" areas that possess broadband with one or more areas that lack broadband that have similar observable characteristics.

Fortunately, a number of methods for estimating ATET relying on the conditional independence assumption (CIA) have been introduced that may result in unbiased estimates. Simple matching estimator and propensity-score matching techniques have been used in many recent studies (e.g., Dehejia and Wahba, 1999; Hirano and Imbens, 2001; Trujillo, Portillo, and Vernon, 2005). Still, simple matching estimators can provide biased estimates, especially when the matching is not precise (Abadie and Imbens, 2002; Hirano, Imbens, and Ridder, 2003; Imbens, 2004).

Unlike the simple matching estimator, the propensity score method does not directly adjust for all covariates. Instead, it focuses on adjusting the propensity score, which is the conditional probability of receiving the treatment (i.e. having broadband access). This method uses the propensity score, which is based on observable predictors, to group treated and nontreated units that have similar scores. This should prevent bias from poor matches, especially when we have many observable characteristics (Rosenbaum and Rubin, 1983, 1985; Hirano, Imbens, and Ritter, 2003). 
We apply a logit model to estimate the propensity score. This estimate is then used to match treated and nontreated units by creating blocks that contain units with similar propensity scores. To avoid bias in estimation of the ATET due to an incorrect specification of the propensity score, we use an algorithm developed by Becker and Ichino (2002) to test whether the logit model meets a specific balancing property. This tests whether the treated and nontreated groups of each block have the same distribution of covariates, and ensures that the components of covariates are balanced. By using this test, we can calibrate the logit model until the balancing property is satisfied-signifying similarity of observations in the treated and control groups. Even though we have a propensity score that satisfies the balancing property, the continuous nature of the propensity score variable prevents us from having units in the treated and nontreated groups with exactly the same value. The question is then how to match observations. In order to ensure robustness of our results, both nearest neighbor matching and kernel matching techniques will be employed to estimate broadband's effect on migration. ${ }^{7}$

The nearest neighbor matching technique matches the treated unit with nontreated units for each potential outcome by taking every treated unit and searching for the nontreated unit with the closest propensity score. Still, sometimes these matches may be poor because the difference between propensity scores of treated and nearest nontreated units are huge. Kernel matching solves this problem by matching each treated unit with a weighted average of all nontreated units using weights that are inversely proportional to the distance between the propensity scores of treated and nontreated units. This effect controls for the problem faced by the nearest matching technique (Becker and Ichino, 2002).

Unlike the spatial econometric analysis, which focuses on a single aggregate model, we estimate the ATET of broadband on migration in several distinct cases. First, we compare the areas with at least one type of broadband to areas with no broadband access. We then restrict our observations to areas with both types of broadband and areas with no broadband availableeffectively leaving out those areas with only one type of access. We also allow the ATET to differ by rural and urban location.

\section{DATA DESCRIPTION}

The data used in this study come from a number of publicly available secondary sources. Migration rates at the county level in the U.S. between 2000 and 2006 are obtained from the U.S. Census Bureau. We include both the total and domestic migration rates in various specifications. Industrial shares in employment, the employment level, average housing value, and the poverty rate are also collected from the U.S. Census Bureau. The rural dummy variable is created by assigning a zero to all counties designated metropolitan by the U.S. Office of Management and Budget and one to all other counties. The County and City Data Book 2000 edition provides information on per capita crime rates and per capita social security benefits. We use State and Local Government Finances provided by the U.S. Census to collect the county-level government expenditures.

\footnotetext{
${ }^{7}$ Details of propensity score technique and the balancing algorithm used are provided in Becker and Ichino (2002) and Dehejia and Wahba (2002).
} 


\section{FIGURE 2. County Broadband Availability in 2000}

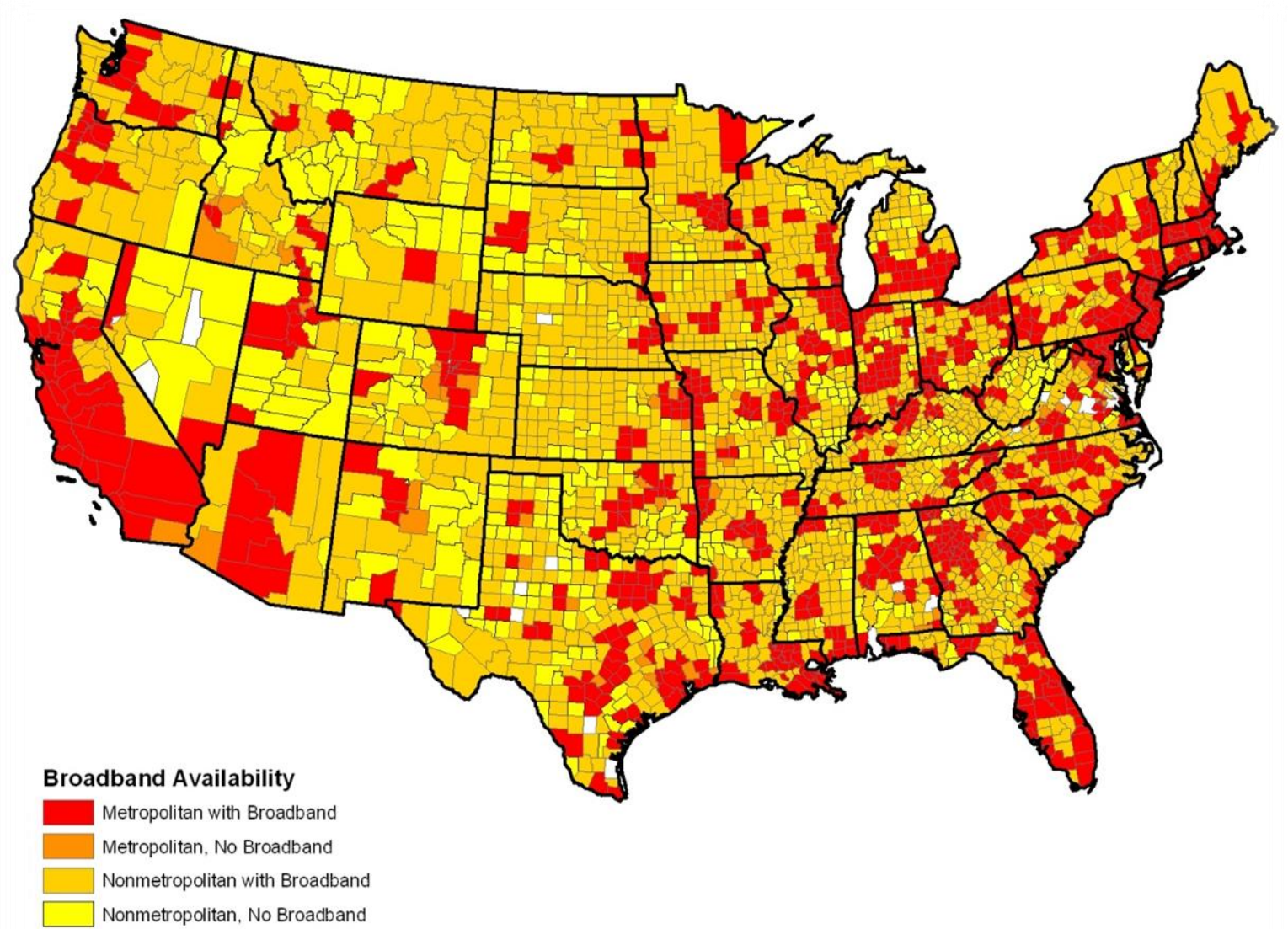

Source: Cable Television Factbook, FCC Tariff \# 4 Data for 2000.

The broadband dataset is taken from sources on Cable Internet and DSL infrastructure in 2000, as these technologies composed over 95 percent of residential high-speed lines at that time (Federal Communications Commission, 2001). The Cable TV Factbook provides details on each existing Cable system in operation (over 6,500 in 2000), including whether or not they offered broadband access, and lists all of the counties serviced. The FCC's Tariff \#4 dataset, made available by the National Exchange Carriers Association (NECA), provides information on the DSL capability of every central office switch in the United States (over 35,000 in 2000) along with the city served by each switch. ${ }^{8}$ Although these binary measures do not fully capture the degree of broadband coverage within a county, they are an improvement over the commonly used FCC Form 477 data. This is because the data used here represents the presence of wired infrastructure while the FCC data has been highly criticized for only capturing where subscribers exist (Government Accountability Office, 2006), and would therefore potentially show a ZIP code with a single satellite subscriber as having broadband infrastructure available. ${ }^{9}$ Figure 2 displays the county-level broadband infrastructure data by rural/urban status as of the year 2000 . In addition, descriptive statistics of the variables used are displayed in Table 1.

\footnotetext{
${ }^{8}$ Grubesic (2008) stated that the FCC data for DSL availability may be overestimated at the local level if researchers assume that every household in a ZIP code with DSL can access it. This is due to the fact that the range of DSL capability is about 1.5 miles from its central office. Households located further than this range may not be able to access DSL even though they are in the same ZIP code where DSL is reportedly available.

${ }^{9}$ More detailed information on these sources can be found in Whitacre and Mills (2007).
} 
TABLE 1. Descriptive Characteristics of Counties with and without Broadband Access

\begin{tabular}{|c|c|c|c|c|c|c|c|c|}
\hline \multirow[b]{2}{*}{ Variable } & \multirow[b]{2}{*}{$\begin{array}{c}\text { All } \\
\text { counties }\end{array}$} & \multirow[b]{2}{*}{$\begin{array}{l}\text { Standard } \\
\text { deviation }\end{array}$} & \multicolumn{6}{|c|}{ Counties with: } \\
\hline & & & $\begin{array}{c}\text { Cable } \\
\text { and } \\
\text { DSL }\end{array}$ & $\begin{array}{l}\text { Standard } \\
\text { deviation }\end{array}$ & Broadband & $\begin{array}{l}\text { Standard } \\
\text { deviation }\end{array}$ & $\begin{array}{c}\text { No } \\
\text { broadband }\end{array}$ & $\begin{array}{l}\text { Standard } \\
\text { deviation }\end{array}$ \\
\hline Total migration rate & 0.015 & 0.078 & 0.024 & 0.084 & 0.016 & 0.077 & 0.010 & 0.080 \\
\hline Domestic migration rate & 0.006 & 0.077 & 0.015 & 0.083 & 0.008 & 0.076 & 0.001 & 0.080 \\
\hline Employment & 42031 & 131217 & 78370 & 196459 & 50265 & 144559 & 7041 & 8753 \\
\hline Household income & 35305 & 8857 & 38136 & 8913 & 36080 & 8976 & 32011 & 7494 \\
\hline Housing value & 83984 & 47826 & 95168 & 43865 & 86479 & 46902 & 73379 & 50247 \\
\hline Poverty rates & 0.137 & 0.063 & 0.123 & 0.055 & 0.133 & 0.061 & 0.152 & 0.067 \\
\hline \multicolumn{9}{|l|}{ Industrial shares } \\
\hline Agriculture (11) ${ }^{1}$ & 0.061 & 0.069 & 0.038 & 0.045 & 0.054 & 0.065 & 0.089 & 0.081 \\
\hline Construction (23) & 0.076 & 0.023 & 0.075 & 0.021 & 0.075 & 0.022 & 0.081 & 0.029 \\
\hline Manufacturing (31-33) & 0.158 & 0.090 & 0.169 & 0.084 & 0.164 & 0.089 & 0.135 & 0.094 \\
\hline Wholesale trade (42) & 0.030 & 0.011 & 0.032 & 0.010 & 0.031 & 0.011 & 0.027 & 0.012 \\
\hline Retail trade (44-45) & 0.115 & 0.020 & 0.120 & 0.017 & 0.117 & 0.019 & 0.110 & 0.022 \\
\hline Finance $(52)$ & 0.046 & 0.018 & 0.051 & 0.020 & 0.047 & 0.019 & 0.041 & 0.015 \\
\hline Public administration (92) & 0.053 & 0.030 & 0.048 & 0.027 & 0.052 & 0.028 & 0.059 & 0.034 \\
\hline Crime rate/pop & 0.024 & 0.018 & 0.030 & 0.019 & 0.026 & 0.018 & 0.018 & 0.017 \\
\hline $\begin{array}{l}\text { Government } \\
\text { expenditure/pop }\end{array}$ & 2.326 & 1.261 & 2.473 & 0.992 & 2.376 & 1.273 & 2.113 & 1.186 \\
\hline Social security benefit/pop & 0.349 & 0.055 & 0.357 & 0.047 & 0.351 & 0.050 & 0.338 & 0.070 \\
\hline Amenities index & 3.486 & 1.054 & 3.476 & 1.114 & 3.440 & 1.048 & 3.684 & 1.059 \\
\hline Rural & 0.651 & 0.477 & 0.481 & 0.500 & 0.603 & 0.489 & 0.856 & 0.352 \\
\hline $\begin{array}{l}\text { Counties with Cable and } \\
\text { DSL }\end{array}$ & 0.371 & 0.483 & & & & & & \\
\hline $\begin{array}{l}\text { Counties with at least one } \\
\text { type of broadband }\end{array}$ & 0.810 & 0.393 & & & & & & \\
\hline Number of counties & 2,987 & & 1,108 & & 2,418 & & 569 & \\
\hline
\end{tabular}

\section{EMPIRICAL RESULTS}

\subsection{Spatial Regression results}

The spatial regression results for the total and domestic net migration rates are presented in Table 2 for the spatial error model. Results from the aspatial (OLS), spatial lag and general spatial models are included in Table A1 in the Appendix. Because of the importance of preserving the spatial relationship among observations, we do not estimate a separate regression for urban and rural counties. The results reflect the dataset containing all observations (urban and rural) and include a single broadband variable that denotes whether at least one broadband platform is present in the county. As preferences for domestic migrants might differ from those of foreign migrants, we considered the migration rate for all migrants (total net migration rate) and for only domestic migrants (domestic net migration rate) as dependent variables. These measures focus on true migration as they are free from birth and death statistics. While the LM tests suggest that the general spatial model is the most appropriate for this analysis (see Table A2 for LM test results), we chose the spatial error model results to present here. One will notice, if they compare the data in the appendix, that the general spatial model parameter 
TABLE 2. Spatial Error Regression Results

\begin{tabular}{|c|c|c|}
\hline Variable & $\begin{array}{l}\text { Net Total } \\
\text { Migration } \\
\end{array}$ & $\begin{array}{c}\text { Net Domestic } \\
\text { Migration }\end{array}$ \\
\hline $\operatorname{Ln}($ Employ $)$ & $\begin{array}{c}0.007 * * * \\
(3.326)\end{array}$ & $\begin{array}{c}0.007 * * * \\
(3.143)\end{array}$ \\
\hline $\operatorname{Ln}($ Income $)$ & $\begin{array}{l}-0.023^{*} \\
(-1.803)\end{array}$ & $\begin{array}{c}-0.035 * * * \\
(-9.110)\end{array}$ \\
\hline Ln(Housing Value $)$ & $\begin{array}{c}0.021 * * * \\
(2.899)\end{array}$ & $\begin{array}{c}0.018 * * * \\
(2.675)\end{array}$ \\
\hline Poverty Rate & $\begin{array}{c}-0.026 \\
(-0.701)\end{array}$ & $\begin{array}{l}-0.055^{*} \\
(-1.918)\end{array}$ \\
\hline Agriculture & $\begin{array}{c}0.106 * * * \\
(2.823)\end{array}$ & $\begin{array}{c}0.091 * * \\
(2.396)\end{array}$ \\
\hline Construction & $\begin{array}{c}0.411 * * * \\
(5.551)\end{array}$ & $\begin{array}{c}0.424 * * * \\
(5.653)\end{array}$ \\
\hline Manufacturing & $\begin{array}{c}0.092 * * * \\
(3.719)\end{array}$ & $\begin{array}{c}0.089 * * * \\
(3.604)\end{array}$ \\
\hline Wholesale Trade & $\begin{array}{c}0.150 \\
(1.087)\end{array}$ & $\begin{array}{c}0.077 \\
(0.558)\end{array}$ \\
\hline Retail Trade & $\begin{array}{c}0.259 * * * \\
(3.008)\end{array}$ & $\begin{array}{c}0.257 * * * \\
(3.048)\end{array}$ \\
\hline Finance & $\begin{array}{c}-0.013 \\
(-0.117)\end{array}$ & $\begin{array}{c}0.021 \\
(0.189)\end{array}$ \\
\hline Public Administration & $\begin{array}{c}0.266^{* * * *} \\
(4.494)\end{array}$ & $\begin{array}{c}0.257 * * * \\
(4.270)\end{array}$ \\
\hline Per Capita Crimes & $\begin{array}{c}0.054 \\
(0.569)\end{array}$ & $\begin{array}{c}0.009 \\
(0.092)\end{array}$ \\
\hline Per Capita Social Security Benefits & $\begin{array}{c}-0.022 \\
(-0.756)\end{array}$ & $\begin{array}{c}-0.020 \\
(-0.691)\end{array}$ \\
\hline Per Capita Local Gov't Expenditures & $\begin{array}{c}-0.002 \\
(-1.520)\end{array}$ & $\begin{array}{l}-0.002 * \\
(-1.663)\end{array}$ \\
\hline Amenity Score & $\begin{array}{c}0.007 * * * \\
(3.586)\end{array}$ & $\begin{array}{c}0.005 * * \\
(2.562)\end{array}$ \\
\hline Rural Dummy & $\begin{array}{c}-0.001 \\
(-0.259)\end{array}$ & $\begin{array}{c}-0.001 \\
(-0.192)\end{array}$ \\
\hline Broadband Dummy & $\begin{array}{c}0.000 \\
(-0.007)\end{array}$ & $\begin{array}{c}0.001 \\
(0.345)\end{array}$ \\
\hline$\lambda$ (spatial error parameter) & $\begin{array}{c}0.241 * * * \\
(33.431)\end{array}$ & $\begin{array}{c}0.227 * * * \\
(22.923)\end{array}$ \\
\hline Constant & $\begin{array}{c}-0.158 \\
(-1.440)\end{array}$ & $\begin{array}{c}0.002 \\
(0.066)\end{array}$ \\
\hline Log Likelihood & $4,605.555$ & $4,585.373$ \\
\hline$R^{2}$ & 0.117 & 0.097 \\
\hline Number of Observation & 2,987 & 2,987 \\
\hline
\end{tabular}


estimates deviate substantially in magnitude and sign from the other three models (for both total migration and domestic migration as dependent variables), suggesting that it is misspecified relative to the other models. The spatial error model has the highest explanatory power of the remaining models, so those results are featured here.

The sign and significance of the coefficient on the broadband dummy variable is of primary interest. This coefficient suggests that the presence of some type of broadband (DSL or Cable) had no statistically significant impact on either net migration rate (total or domestic) holding all other factors constant ${ }^{10}$. Income and housing value have opposite signs than hypothesized; the results suggest that counties with lower wages or higher property values increase net migration rate. One explanation for these results might be that higher wages and lower housing values could discourage residents from leaving the community (i.e., they have a higher reservation utility), rather than higher wages and lower housing values attracting migrants to a community. Alternatively, the positive and significant parameter on employment levels may imply that the potential for employment might drive migration decisions. Several of the industrial employment shares parameters were significant: agriculture, construction, manufacturing, retail, and public administration. Each of these sectors demonstrated positive parameter estimates, suggesting that higher employment shares in these sectors induce new residents. Given that most of these industries are labor-intensive, these results are intuitive. The only remaining variable that demonstrates significance is the amenity score, which is positive and highly significant, as expected. The lack of significance for several intuitive variables such as crimes or government expenditures implies that these measures are not exceedingly important in the migration decision. The $R^{2}$ values of 0.117 and 0.097 , for the total and domestic migration variables respectively, suggest that the model has a satisfactory (if somewhat low) fit. Finally, we note that the results are strikingly similar for the regressions on total population and domestic migration. ${ }^{11}$ Given that these two variables are very similar to one another, this result is not unexpected.

\subsection{Treatment Effect}

\subsubsection{Propensity Score Models}

Unlike the spatial model, we use two distinct cases to clarify the effect of broadband on migration. For the first case, we compare counties with at least one type of broadband to those with no broadband. The second case compares counties with both Cable and DSL access (a more intensive measure of broadband access) to counties without any type of broadband. This requires two sets of propensity score models to be estimated. The matching strategy relies on the conditional independence assumption (CIA). In the case of the propensity-score matching method, there is some debate about whether variables included in the propensity score model should affect both the availability of broadband (participation decision) and the migration decision (outcome variables) (Ham, Li, and Reagan, 2005; Caliendo and Kopeinig, 2008). Hence, our propensity score specifications include one model that incorporates only the variables that should affect both the availability of broadband and migration, and another model that incorporates these variables in addition to variables that should only influence the migration decision.

\footnotetext{
${ }^{10}$ It is worth noting that the parameter estimate for broadband was insignificant across all four models estimated for both dependent variables.

${ }^{11}$ For the model with domestic migration as its dependent variable, two additional variables are significant: poverty (which is negative, as predicted) and local government per capita expenditures (which is also negative).
} 
The true functional forms of propensity score models are not known. We apply the algorithm developed by Becker and Ichino (2002) to test the necessary condition for the balancing property, which ensures that the estimated propensity scores and observable characteristics between treated and non-treated units are statistically identical. This test allows us to calibrate the logit models until the balancing property is reached, and is the reason why some variables are not included in certain specifications. ${ }^{12}$

Table 3 reports four sets of logit estimates for the availability of broadband. The dependent variable in models 1 and 2 is coded to one if a county has at least one type of broadband and zero otherwise. The difference between model 1 and model 2 is that model 1 contains variables that affect both availability of broadband and migration decision and variables that may only influence the migration decision by itself, such as amenity score, per capita social security income, and per capita crime rate. Model 2 only contains variables that may affect both the availability of broadband and migration decision such as the share of employment in particular industries, education, and rural location. The coefficients of these two logit models are consistent with most broadband studies. For example, counties with higher income and population density are more likely to have broadband available, while the digital divide between rural and urban areas still exists (i.e. the rural dummy is negative and significant).

Turning now to models 3 and 4, the dependent variable is switched to a more restrictive measure of broadband availability. Counties with both Cable and DSL are coded to one, while counties without broadband access are coded zero-effectively leaving out approximately 1,300 counties with just one type of broadband. The difference between models 3 and 4 is the same as that between model 1 and model 2. Namely, model 3 contains two categories of variables, which are the variables affecting the migration decision only, and the variables influencing both the migration decision and the availability of broadband. Model 4 includes only the latter type of variable. Similar to the model 1 and model 2 results, most coefficients have the expected sign and are consistent with previous broadband studies. However, most coefficients of model 4 are significantly larger than those of model 3. This may be a sign of biased estimates from omitting important variables (Heckman, Ichimura, and Todd, 1997; Dehejia and Wahba, 1999).

\subsubsection{Estimates of Broadband Effects on Migration}

Table 4 represents the effects of the availability of at least one type of broadband on net total migration rate and net domestic migration rate estimated by both the kernel matching method and the nearest matching method. ${ }^{13}$ The standard errors of those two methods are calculated with 1,000 bootstrap repetitions. Starting with the kernel matching method, when all areas are estimated together, the effects of the availability of at least one type of broadband are positive in both total migration and domestic migration. These effects, however, are only statistically significant for the domestic, suggesting that areas with at least one type of broadband experience net domestic migration 0.7 percent higher than those without it. In addition, the estimates from model 1 and model 2 are very similar in terms of both the broadband

\footnotetext{
${ }^{12}$ To check the sensitivity of the treatment effect method due to a change in propensity score models, we test the balancing property at both the 1 and 5 percent levels of significance. Only the 1 percent level results are reported here due to the similarity between them.

${ }^{13}$ In addition to testing the balancing property for the kernel and nearest matching method at the 1 and 5 percent significance levels, we also apply the simpler matching technique based on nearest neighbor matching developed by Abadie and Imbens (2002). This method allows us to reduce bias, which could occur when the matching is not exact. Generally, the treatment effect results estimated by this technique are similar to those obtained from the propensity score matching techniques.
} 
TABLE 3. Logit Models to Estimate the Propensity Score for Areas with (1) at Least One Type of Broadband and (2) Both Types of Broadband

\begin{tabular}{|c|c|c|c|c|}
\hline \multirow{2}{*}{ Variable } & \multicolumn{2}{|c|}{ Broadband } & \multicolumn{2}{|c|}{ Cable \& DSL } \\
\hline & Model 1 & Model 2 & Model 3 & Model 4 \\
\hline $\operatorname{Ln}($ income $)$ & $\begin{array}{c}0.944 * * \\
(2.389)\end{array}$ & $\begin{array}{c}0.398 \\
(1.015)\end{array}$ & $\begin{array}{c}1.516 * * * \\
(2.771)\end{array}$ & $\begin{array}{c}0.887 * * \\
(2.077)\end{array}$ \\
\hline $\operatorname{Ln}($ popdensity) & & $\begin{array}{c}0.580 * * * \\
(9.130)\end{array}$ & $\begin{array}{c}2.263 * * * \\
(8.737)\end{array}$ & \\
\hline $\operatorname{Ln}\left(\right.$ popdensity $\left.{ }^{2}\right)$ & & & $\begin{array}{c}-0.185^{* * *} \\
(-6.379)\end{array}$ & \\
\hline Agriculture & & $\begin{array}{c}2.339 * * \\
(2.401)\end{array}$ & $\begin{array}{c}4.664 * * \\
(2.258)\end{array}$ & \\
\hline Construction & $\begin{array}{l}-7.493 * * * \\
(-3.309)\end{array}$ & & $\begin{array}{c}-12.169 * * * \\
(-3.599)\end{array}$ & \\
\hline Manufacturing & $\begin{array}{l}2.768 * * * \\
(3.849)\end{array}$ & $\begin{array}{c}0.552 \\
(0.645)\end{array}$ & $\begin{array}{c}-1.535 \\
(-1.265)\end{array}$ & $\begin{array}{c}7.217 * * * \\
(8.632)\end{array}$ \\
\hline Wholesale trade & $\begin{array}{l}8.991^{*} \\
(1.810)\end{array}$ & $\begin{array}{l}5.888 \\
(1.205)\end{array}$ & & $\begin{array}{c}25.427 * * * \\
(4.260)\end{array}$ \\
\hline Transportation & $\begin{array}{l}-5.021 \\
(-1.479)\end{array}$ & & $\begin{array}{c}-10.688^{* *} \\
(-2.269)\end{array}$ & \\
\hline Finance & $\begin{array}{c}4.610 \\
(1.070)\end{array}$ & $\begin{array}{c}-6.196 \\
(-1.454)\end{array}$ & $\begin{array}{c}0.841 \\
(0.145)\end{array}$ & $\begin{array}{c}13.894 * * * \\
(2.797)\end{array}$ \\
\hline Public Administration & & $\begin{array}{c}-1.239 \\
(-0.651)\end{array}$ & $\begin{array}{c}-5.901 * * \\
(-2.243)\end{array}$ & \\
\hline High school & $\begin{array}{c}-0.276 \\
(-0.230)\end{array}$ & $\begin{array}{c}0.270 \\
(0.234)\end{array}$ & $\begin{array}{c}0.639 \\
(0.404)\end{array}$ & \\
\hline College & $\begin{array}{c}-0.763 \\
(-0.799)\end{array}$ & $\begin{array}{c}3.057 * * * \\
(3.026)\end{array}$ & $\begin{array}{c}4.060 * * * \\
\mid(2.819)\end{array}$ & $\begin{array}{c}2.931 * * * \\
(2.845)\end{array}$ \\
\hline Graduate degree & $\begin{array}{c}3.742 \\
(1.090)\end{array}$ & $\begin{array}{l}-6.024^{*} \\
(-1.785)\end{array}$ & $\begin{array}{c}-10.914 * * \\
(-2.577)\end{array}$ & $\begin{array}{c}8.007 * * \\
(2.304)\end{array}$ \\
\hline Amenities & $\begin{array}{c}-0.216^{* * *} \\
(-3.742)\end{array}$ & & $\begin{array}{c}-0.114 \\
(-1.443)\end{array}$ & \\
\hline Per capital social security income & & & $\begin{array}{l}1.010 \\
(0.692)\end{array}$ & \\
\hline Per capita government expenditure & $\begin{array}{c}0.062 \\
(1.148)\end{array}$ & & & \\
\hline Per capita crime rate & $\begin{array}{l}20.741 * * * \\
(5.699)\end{array}$ & & $\begin{array}{l}23.091 * * * \\
(5.267)\end{array}$ & \\
\hline Rural dummy & $\begin{array}{c}-0.810 * * * \\
(-5.328)\end{array}$ & $\begin{array}{c}-0.387 * * \\
(-2.465)\end{array}$ & $\begin{array}{c}-0.425^{* *} \\
(-2.213)\end{array}$ & $\begin{array}{c}-1.051 * * * \\
(-6.528)\end{array}$ \\
\hline Constant & $\begin{array}{c}-7.454 * * \\
(2.050)\end{array}$ & $\begin{array}{c}-5.374 \\
(-1.469)\end{array}$ & $\begin{array}{c}-20.363 * * * \\
(-4.020)\end{array}$ & $\begin{array}{c}-11.850^{* * *} \\
(-2.832)\end{array}$ \\
\hline Pseudo $R^{2}$ & 0.108 & 0.116 & 0.328 & 0.198 \\
\hline Log-likelihood & -1297.407 & -1285.118 & -722.209 & -861.296 \\
\hline No. of Observations & 2987 & 2987 & 1677 & 1677 \\
\hline
\end{tabular}

(C) Southern Regional Science Association 2011. 
TABLE 4. Average Effect of Having at Least Cable or DSL on Migration Based on Two Alternative Logit Models

\begin{tabular}{lcccccc}
\hline \multirow{2}{*}{ Net Migration } & \multicolumn{3}{c}{ All Areas } & \multicolumn{2}{c}{ Rural Areas } & \multicolumn{2}{c}{ Urban Areas } \\
\cline { 2 - 7 } & Model 1 & Model 2 & Model 1 & Model 2 & Model 1 & Model 2 \\
\hline \multirow{3}{*}{ Net Total Migration } & 0.006 & 0.006 & 0.001 & 0.001 & 0.012 & $0.015^{*}$ \\
& $(0.004)$ & $(0.004)$ & $(0.004)$ & $(0.004)$ & $(0.009)$ & $(0.008)$ \\
Net Domestic Migration & $0.007 *$ & $0.007 *$ & 0.002 & 0.002 & $0.016^{*}$ & $0.020^{* *}$ \\
& $(0.004)$ & $(0.004)$ & $(0.004)$ & $(0.004)$ & $(0.009)$ & $(0.009)$ \\
Net Total Migration & $0.008^{*}$ & $0.010^{* *}$ & 0.001 & -0.003 & $0.015^{*}$ & $0.031^{* * *}$ \\
& $(0.004)$ & $(0.005)$ & $(0.005)$ & $(0.006)$ & $(0.008)$ & $(0.010)$ \\
Net Domestic Migration & $0.013^{* * * *}$ & $0.014 * * *$ & 0.003 & -0.003 & $0.024^{* * *}$ & $0.042^{* * *}$ \\
& $(0.005)$ & $(0.005)$ & $(0.005)$ & $(0.006)$ & $(0.009)$ & $(0.011)$ \\
\hline \hline Notes: Standard errors calculated from 1,000 bootstrap repetitions are in parentheses. **, **, and * represent significant level at 1\%,5\%, and \\
10\%, respectively.
\end{tabular}

effects and standard errors. This would imply that the variables that are expected to influence the migration decision only (amenity score, per capita social security income, and per capita crime rate) may not provide extra information regarding the migration decision after controlling for other county characteristics. When we disaggregate our sample into rural and urban areas, the effect of availability of at least one type of broadband on migration is still positive in both cases. However, these effects are very small and are statistically insignificant in all rural cases. For urban areas, on the other hand, the results are larger and generally significant, suggesting net migration rates 1.5 to 2 percent higher in urban areas with access than in urban areas without access.

When the nearest matching method is applied, the effects of having at least one type of broadband available are relatively larger than those from the kernel matching technique for almost all cases. Generally, the results are similar to those from the kernel method, with differences in net domestic migration being positive and significant for all areas and urban areas. In addition, net total migration is now positive and significant for the models using all counties and urban counties, with results ranging from an expected increase of 0.8-1.0 percent (all areas) to 1.5-4.2 percent (urban areas). When we restrict our analysis to rural areas, however, this effect is still not significant in any case and actually becomes negative but not statistically significant in model 2.

We also estimate the effect of broadband on net migration rate by comparing areas with both Cable and DSL to areas with no broadband at all. The estimation strategies of this case are the same as for the former scenario. The only difference is that the observations are restricted to areas with both types of broadband and those without any types of broadband. Table 5 presents the estimates based on these observations. In the kernel matching panel, the effects of having both types of broadband on migration are positive and statistically significant for the cases of all areas and urban areas. Counties with both types of broadband tend to have 1.2 to 1.9 percent higher levels of net total migration and 1.5 to 2.3 percent higher levels of net domestic migration than those without them. In a similar manner, urban counties with both types of broadband experience higher net total migration (1.5 to 2.9 percent) and net domestic migration (2.3 to 3.5 


\section{TABLE 5. Average Effect of Having both Cable and DSL on Migration Based on Two Alternative Logit Models}

\begin{tabular}{lcccccc}
\hline \multirow{2}{*}{ Net Migration } & \multicolumn{3}{c}{ All Areas } & \multicolumn{2}{c}{ Rural Areas } & \multicolumn{3}{c}{ Urban Areas } \\
\cline { 2 - 7 } & Model 3 & Model 4 & Model 3 & Model 4 & Model 3 & Model 4 \\
\hline \multirow{3}{*}{ Net Total Migration } & $0.019^{* * *}$ & $0.012^{* *}$ & 0.009 & 0.007 & $0.029 * * *$ & $0.018^{*}$ \\
& $(0.005)$ & $(0.006)$ & $(0.006)$ & $(0.006)$ & $(0.010)$ & $(0.010)$ \\
Net Domestic Migration & $0.023^{* * *}$ & $0.015^{* *}$ & $0.011^{*}$ & 0.008 & $0.035^{* * *}$ & $0.023^{* *}$ \\
& $(0.006)$ & $(0.006)$ & $(0.006)$ & $(0.006)$ & $(0.012)$ & $(0.010)$ \\
& \multicolumn{7}{c}{ Nearest matching method } \\
Net Total Migration & $0.025^{* * *}$ & $0.012^{* *}$ & $0.014^{* *}$ & 0.010 & $0.029^{*}$ & $0.020^{* *}$ \\
& $(0.008)$ & $(0.006)$ & $(0.007)$ & $(0.007)$ & $(0.016)$ & $(0.009)$ \\
Net Domestic Migration & $0.028^{* * *}$ & $0.015^{* *}$ & $0.016^{* *}$ & 0.010 & $0.027 * *$ & $0.025^{* *}$ \\
& $(0.009)$ & $(0.007)$ & $(0.007)$ & $(0.007)$ & $(0.016)$ & $(0.010)$ \\
\hline
\end{tabular}

percent). In addition, broadband's impact for rural areas is now statistically significant at the 10 percent level for net domestic migration. The results suggest that rural areas with both types of broadband tend to have levels of net domestic migration rate 1.1 percent higher than those without them.

When the nearest matching method is used, the results are similar to those obtained under the kernel matching method. The effects, however, are generally larger than those from the kernel matching method. Namely, the effects of both types of broadband on net total migration and net domestic migration for all observations and urban observations range from 1.2 to 2.9 percent. The interesting result from this estimation is that the availability of both types of broadband in rural counties not only affects net domestic migration but also affects net total migration, because the effects are statistically significant for both cases. This is shown in model 3 in the rural area column. Rural counties with both types of broadband have 1.4 percent higher net total migration and 1.6 percent higher net domestic migration than those without any type of broadband. GIS mapping techniques allow for visualization of where these counties are located (Figure 3). Counties with both types of broadband access and positive in-migration are located across the west coast, throughout the south, and dispersed across several central states. Many counties in the Central region, however, experienced out-migration even though both types of broadband were available. This implies that, as the small effects in Table 5 suggest, other factors were seemingly more important in the migration decision.

\section{DISCUSSION AND CONCLUSION}

The spatial econometric model estimates the effect of broadband on total and domestic migration for the entire dataset of both rural and urban counties. The results suggest that spatial interdependence of migration exists, based on the statistical significance of spatially correlated errors and improved results from the aspatial model. Most coefficients of the spatial-error model are consistent with previous migration studies. The dummy variable for any broadband access is not statistically significant, however. Thus, the takeaway from the spatial econometric model is that the availability of broadband access may not be key in attracting new residents. 
FIGURE 3. Migration Pattern of Counties with Both Cable and DSL in 2000

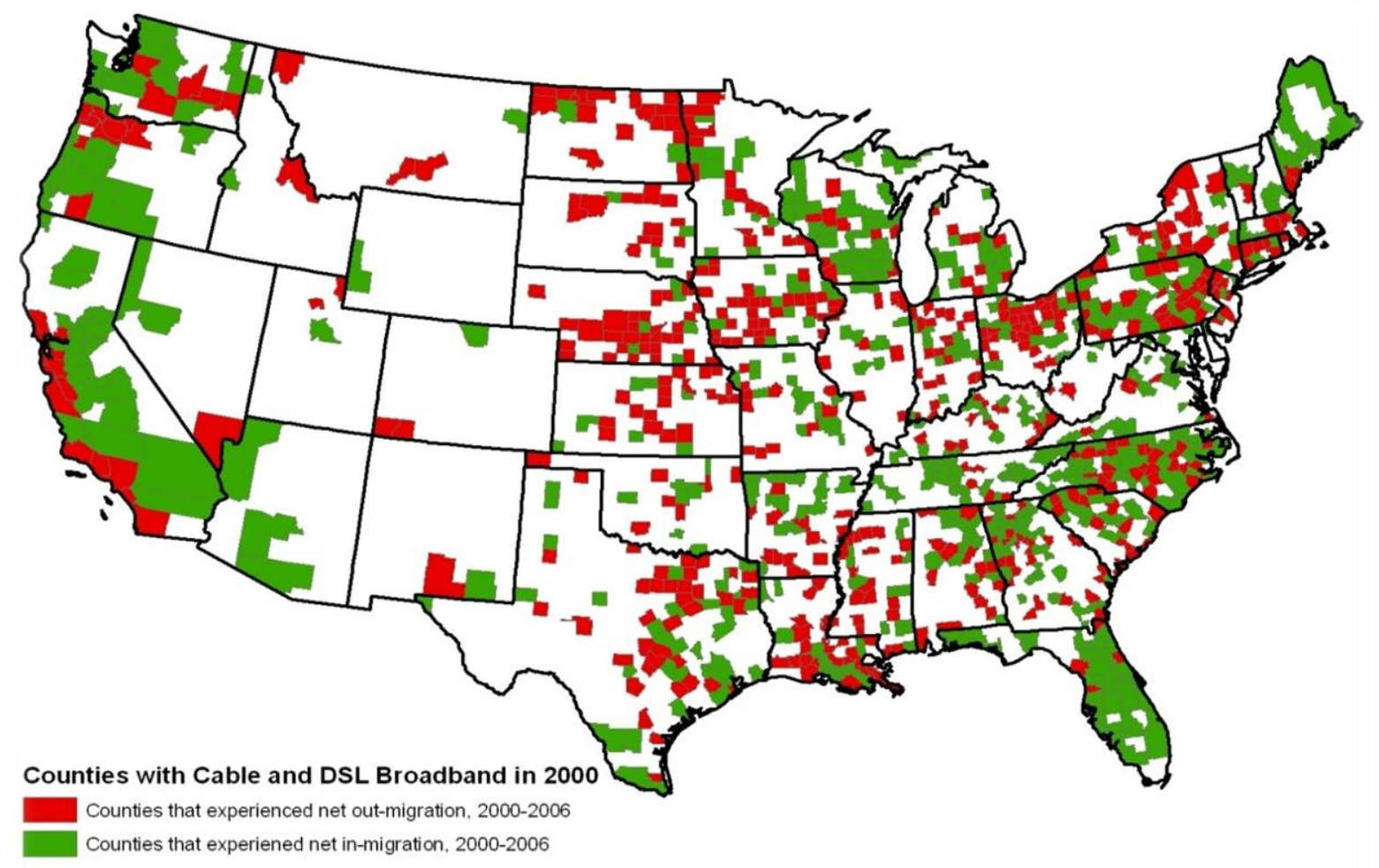

Sources: U.S. Census Bureau, Cable Television Factbook, FCC Tariff \# 4 Data for 2000.

The spatial econometric model may not provide the best assessment of broadband's impact on migration. Although existing research and GIS analysis of migration data for this period suggest interdependence between rural and urban places, we cannot be certain that the inclusion of spatial-error terms is not washing out the impact of other potentially important spatial variables (such as broadband). Furthermore, regression cannot establish causation, and given the potential endogeneity between migration and broadband availability, this is an important consideration for our analysis. Therefore, the average treatment effect is used, which allows us to explicitly compare rural or urban counties with and without broadband access.

The average treatment effect estimates show several important results. The first one is that, generally, we do not find a strong impact of broadband on migration, particularly for rural areas. Even though most estimates show a positive impact of broadband on migration, most of the statistically significant values are fairly small. In addition, when we consider this impact for rural counties only, the impact of the availability of at least one type of broadband on migration is never statistically significant, and is actually negative in some cases.

This result may give further credence to the idea that rural broadband is not a one-way street for attracting residents. In particular, some rural areas with at least one type of broadband may actually experience outmigration when compared to rural areas that lack broadband access. Evidence for this has also been found by Egan (2002) and LaRose et al. (2008). In the LaRose study, broadband access in rural areas actually encouraged outmigration because residents used 
the technology to search for jobs in nearby cities and then moved away. This situation, however, may not hold absolutely true for all cases. When we restrict our observations to rural areas with both Cable and DSL (a more intensive measure of broadband access), the impact on migration becomes positive and significant for both total and domestic migration.

Our results are somewhat tempered by the fact that the broadband variable only considers counties with infrastructure prior to 2000. Given the dramatic rise of both supply and demand for broadband since that time, our analysis of the period 2000-2006 potentially misses the impact of those counties that added broadband later on (2001-2006). Without a comprehensive list of when each county obtained its broadband infrastructure (which to our knowledge does not exist), the current study provides a starting point for analyzing broadband's impact on migration.

Overall, our attempt to determine whether the presence of broadband access by the year 2000 had an impact on migration finds no support from the spatial econometric model used, and only slight support from the matching methods. The matching method suggests that all counties, and specifically urban counties, with broadband access experience net migration roughly 1 to 4 percent higher than similar counties without broadband access. For rural counties, only those counties having both Cable and DSL access available in 2000 saw increases in net migration when compared to similar counties without broadband.

\section{REFERENCES}

Abadie, Alberto and Guido Imbens. (2002) "Simple and Bias-Corrected Matching Estimators for Average Treatment Effects," NBER Technical Working Paper 283, last accessed January 2009 at http://www.nber.org/paper/t0283.pdf

Adelaja, Soji, Yohannes Hailu, and Majd Abdulla. (2008). "The Economic Impacts of County Population Change in Ohio," last accessed September 2009 at http://www.landpolicy.msu.edu/modules.php?name=Page\&sp_id=292

Anselin, Luc. (1988) Spatial Econometrics: Methods and Models. Dordrecht, Kluwer Academic Publisher: The Netherlands.

(2003) "Spatial Externalities, Spatial Multipliers, and Spatial Econometrics," International Regional Science Review, 26, 153-166.

Aschauer, David. (1989) "Is Public Expenditure Productive?," Journal of Monetary Economics, 23, 177-200.

Becker, Sascha O. and Andrea Ichino. (2002) "Estimation of Average Treatment Effects Based on Propensity Scores," Stata Journal, 2, 358-377.

Boarnet, Marlon G. (1994) "The Monocentric Model and Employment Location," Journal of Urban Economics, 36, 79-97.

Boarnet, Marlon G., Saksith Chalermpong, and Elizabeth Geho. (2005) "Specification Issues in Models of Population and Employment Growth," Papers in Regional Science, 84, 21-46.

Caliendo, Marco and Sabine Kopeinig. (2008) "Some Practical Guidance for the Implementation of Propensity Score Matching," Journal of Economic Survey, 22, 31-72. 
Dehejia, Rajeev H. and Sadek Wahba. (1999) "Causal Effects in Non-experimental Studies: Reevaluating the Evaluation of Training Programs," Journal of the American Statistical Association, 94, 1053-1062.

. (2002) "Propensity Score Matching Methods for Non-Experimental Causal Studies," Review of Economics and Statistics, 84, 151-161.

Deller, Steven C., Tsung-Hsiu Tsai, David W. Marcouiller, and Donald B.K. English. (2001) "The Role of Amenities and Quality of Life in Rural Economic Growth," American Journal of Agricultural Economics, 83, 352-365.

Dust, Andrew, Peter Orazem, and Darin Wohlgemuth. (2008) "Rural Immigrant Population Growth, 1950-2000: Waves or Ripples," Department of Economics Working Paper 08012. Iowa State University.

Egan, Timothy. "Bill Gates Views What He's Sown in Libraries," New York Times, November 6, 2002. Last accessed in February 2011 at http://www.nytimes.com/2002/11/06/us/bill-gates-views-whathe-s-sown-in-libraries.html.

Federal Communications Commission. (2001) "High Speed Services for Internet Access: Subscribership as of December 31, 2000," last accessed September 2009 at http://www.fcc.gov/web/iatd/comp.html

. (2008) "Wireline Competition Bureau Presentation of the Section 706 Report and Broadband Data Gathering Order," last accessed September 2009 at http://www.fcc.gov/WCB_031908_open_meeting_slides.pdf

Ford, Gorge S. and Thomas M. Koutsky. (2005) "Broadband and Economic Development: A Municipal Case Study from Florida,” Review of Urban \& Regional Development Studies, 17, 219-229.

Government Accountability Office. (2006) "Broadband Deployment is Extensive throughout the United States, but it is Difficult to Assess the Extent of Deployment Gaps in Rural Areas," Report to Congressional Committees GAO-06-426, last accessed September 2009 at http://www.gao.gov/cgi-bin/getrpt?GAO-06-426

Gramlich, Edward M. (1994) “Infrastructure Investment: A Review Essay,” Journal of Economic Literature, 32, 1176-1196.

Greenwood, Michael J. (1985) "Human Migration: Theory, Models, and Empirical Studies," Journal of Regional Science, 25, 521-544.

Grubesic, Tony H. (2008) "Spatial Data Constraints: Implications for Measuring Broadband," Telecommunications Policy, 32, 490-502.

Ham, John C., Xianghong Li, and Patricia B. Reagan. (2005) "Propensity Score Matching, a Distance-Based Measure of Migration, and the Wage Growth of Young Men," last accessed November 2008 at http://ssrn.com/abstract=671062

Heckman, James J., Hidehiko Ichimura, and Petra E. Todd. (1997) "Matching as an Econometric Evaluation Estimator: Evidence from Evaluating a Job Training Program," Review of Economic Studies, 64, 605-654. 
Hirano, Keisuke and Guido W. Imbens. (2001) "Estimation of Causal Effects using Propensity Score Weighting: An Application to Data on Right Heart Catheterization," Health Services and Outcomes Research Methodology, 2, 259-278.

Hirano, Keisuke, Guido W. Imbens, and Geert Ridder. (2003) "Efficient Estimation of Average Treatment Effects Using the Estimated Propensity Score," Econometrica, 71, 1161-1189.

Imbens, Guido. (2004) "Nonparametric Estimation of Average Treatment Effects under Exogeneity: A Review," Review of Economics and Statistics, 86, 4-29.

Intelligent Community Forum. (2008) "Broadband and Information Technology as Quality of Life Factors in Economic Development," last accessed October 2008 at http://www.intelligentcommunity.org/index.php/

Johnson, Kenneth. (2006) "Demographic Trends in Rural and Small Town America," Reports on Rural America 1(1). Durham, NH: Carsey Institute, last accessed October 2008 at http://carseyinstitute.unh.edu/publications/Report_Demographics.pdf

Korver, William G. (2008) "Net Neutrality Disagreement between Two Former FCC Chairmen," last accessed January 2009 at http://broadbandcensus.com/2008/06/

LaRose, Robert, Gennifer L. Gregg, Sharon Strover, Joseph Straubhaar, and Nobuya Inagaki. (2008) "Closing the Rural Broadband Gap," last accessed January 2009 at https://www.msu.edu/ larose/ruralbb/

Lehr, William H., Carlos A. Osorio, Sharon E. Gillett, and Marvin A. Sirbu. (2005) "Measuring Broadband's Economic Impact," unpublished paper presented at 33rd Research Conference on Communication, Information, and Internet Policy (TPRC), Arlington VA, 23-25 September.

LeSage, James P. and Kelley Pace. (2008) "Spatial Econometric Modeling of Origin-Destination Flows," Journal of Regional Science, 48, 941-967. . (2009) Introduction to Spatial Econometrics. CRC Press: New York.

McGranahan, David. (1999) "Natural Amenities Drive Rural Population Change," Working paper, Food and Rural Economics Division, Economic Research Service, U.S. Department of Agriculture, last accessed September 2009 at http://www.ers.usda.gov/publications/AER781/

McGranahan, David and Calvin L. Beale. (2002) "Understanding Rural Population Loss,” Rural America, 17, 2-11.

National Center for Frontier Communities. (2000) "Geography of Frontier America: The View at the Turn of the Century," last accessed December 2009 at http://www.frontierus.org/gegraphy.htm

Renkow, Mitch and Dale Hoover. (2000) "Commuting, Migration and Rural-Urban Population Dynamics," Journal of Regional Science, 40, 261-287.

Rosenbaum, Paul R. and Donald B. Rubin. (1983) "The Central Role of the Propensity Score in Observational Studies for Causal Effects," Biometrika, 70, 41-55. 
Rosenbaum, Paul R. and Donald B. Rubin. (1985) "Constructing a Control Group Using Multivariate Matched Sampling Methods That Incorporate the Propensity Score," American Statistician, 39, 33-38.

Shideler, David, Narine Badasyan, and Laura Taylor. (2007) "The Economic Impact of Broadband Deployment in Kentucky," Federal Reserve Bank of St. Louis Regional Economic Development, 3, 88-118.

Stenberg, Peter, Mitch Morehart, Stephen Vogel, John Cromartie, Vince Breneman, and Dennis Brown. (2009) "Broadband Internet's Value for Rural America," Economic Research Service Report No. ERR-78, last accessed September 2009 at http://www.ers.usda.gov/Publications/ERR78/

Todaro, Michael P. and Lydia Maruszko. (1987) "Illegal Migration and U.S. Immigration Reform: A Conceptual Framework," Population and Development Review, 13, 101-114.

Treyz, Gorge I., Dan S. Rickman, and Gary L. Hunt. (1993) "The Dynamics of U.S. Internal Migration," Review of Economics and Statistics, 75, 209-214.

Trujillo, Antonio J., Jorge Portillo, and John Vernon. (2005) "The Impact of Subsidized Health Insurance for the Poor: Evaluation the Colombian Experience Using Propensity Score Matching," International Journal of Health Care Finance and Economics, 5, 211-239.

U.S. Bureau of Economic Analysis. (2003) "Input-Output Accounts Data: 1999 Annual I-O Table Two Digit," last accessed November 2008 at http:/www.bea.doc.gov/bea/dn2/Iohtm\#annual

Van Den Berg, Hendrik. (2001) Economic Growth and Development. McGraw-Hill: New York.

Warren, Martyn. (2007) "The Digital Vicious Cycle: Links between Social Disadvantage and Digital Exclusion in Rural Areas," Telecommunications Policy, 31, 374-388.

Whitacre, Brian E. and Bradford F. Mills. (2007) "Infrastructure and the Rural - Urban Divide in High-speed Residential Internet Access,” International Regional Science Review, 30, 249-273.

Whitacre Brian E. and Phumsith Mahasuweerachai. (2008) "Small Broadband Providers and Federal Assistance Programs: Solving the Digital Divide?," Journal of Regional Analysis \& Policy, 38, 254-268.

Wolff, Richard S. (2008) "Citizen Political Enfranchisement and Information Access: Telecommunications Services in Rural and Remote Areas," Montana Media Partnership Report to the Social Science Research Council, last accessed December 2009 at http://tinyurl.com/ycssk47

Wooldridge, Jeffrey M. (2002) Econometric Analysis of Cross Section and Panel Data. MIT Press: Cambridge, Massachusetts. 
APPENDIX

TABLE A1. Other Regression Results

\begin{tabular}{|c|c|c|c|c|c|c|}
\hline \multirow{2}{*}{ Variable } & \multicolumn{3}{|c|}{ Net Total Migration } & \multicolumn{3}{|c|}{ Net Domestic Migration } \\
\hline & OLS & Spatial lag & General spatial & OLS & Spatial lag & General spatial \\
\hline Ln(Employ) & $\begin{array}{c}0.007 * * * \\
(3.254)\end{array}$ & $\begin{array}{c}0.006 * * * \\
(3.129)\end{array}$ & $\begin{array}{l}0.001^{*} \\
(1.695)\end{array}$ & $\begin{array}{c}0.006 * * * \\
(3.085)\end{array}$ & $\begin{array}{c}0.006 * * * \\
(2.953)\end{array}$ & $\begin{array}{l}0.001^{*} \\
(1.686)\end{array}$ \\
\hline Ln(Income) & $\begin{array}{l}-0.033^{*} \\
(-1.894)\end{array}$ & $\begin{array}{c}-0.023^{* * *} \\
(-1.982)\end{array}$ & $\begin{array}{c}0.003 \\
(1.321)\end{array}$ & $\begin{array}{c}-0.046 * * * * \\
(-2.639)\end{array}$ & $\begin{array}{c}-0.035 * * * \\
(-10.056)\end{array}$ & $\begin{array}{c}0.005^{* *} \\
(2.368)\end{array}$ \\
\hline Ln(Housing Value) & $\begin{array}{c}0.026 * * * \\
(3.790)\end{array}$ & $\begin{array}{c}0.018^{* * * *} \\
(2.851)\end{array}$ & $\begin{array}{c}-0.006 * * * \\
(-3.182)\end{array}$ & $\begin{array}{c}0.023 * * * \\
(3.455)\end{array}$ & $\begin{array}{c}0.016 * * * \\
(2.738)\end{array}$ & $\begin{array}{c}-0.007 * * * * \\
(-3.526)\end{array}$ \\
\hline Poverty Rate & $\begin{array}{l}-0.056 \\
(-1.265)\end{array}$ & $\begin{array}{c}-0.042 * * * * \\
(-3.987)\end{array}$ & $\begin{array}{c}0.010 \\
(1.298)\end{array}$ & $\begin{array}{l}-0.084^{*} \\
(-1.881)\end{array}$ & $\begin{array}{c}-0.067 * * * * \\
(-2.798)\end{array}$ & $\begin{array}{c}0.012 \\
(1.616)\end{array}$ \\
\hline Agriculture & $\begin{array}{c}0.102 * * * \\
(2.883)\end{array}$ & $\begin{array}{c}0.097 * * * * \\
(2.804)\end{array}$ & $\begin{array}{l}0.024 * * \\
(2.141)\end{array}$ & $\begin{array}{l}0.088 * * \\
(2.474)\end{array}$ & $\begin{array}{l}0.086^{* *} \\
(2.456)\end{array}$ & $\begin{array}{l}0.023 * * \\
(2.029)\end{array}$ \\
\hline Construction & $\begin{array}{c}0.423 * * * \\
(5.887)\end{array}$ & $\begin{array}{c}0.366 * * * * \\
(5.228)\end{array}$ & $\begin{array}{c}0.033 \\
(1.312)\end{array}$ & $\begin{array}{c}0.441 * * * \\
(6.113)\end{array}$ & $\begin{array}{c}0.389^{* * * *} \\
(5.501)\end{array}$ & $\begin{array}{c}0.024 \\
(0.917)\end{array}$ \\
\hline Manufacturing & $\begin{array}{c}0.102 * * * \\
(4.467)\end{array}$ & $\begin{array}{c}0.082 * * * \\
(3.633)\end{array}$ & $\begin{array}{c}-0.018^{* *} \\
(-2.430)\end{array}$ & $\begin{array}{c}0.100^{* * * *} \\
(4.331)\end{array}$ & $\begin{array}{c}0.082 * * * * \\
(3.618)\end{array}$ & $\begin{array}{c}-0.020^{* * * *} \\
(-2.687)\end{array}$ \\
\hline Wholesale Trade & $\begin{array}{c}0.201 \\
(1.469)\end{array}$ & $\begin{array}{c}0.158 \\
(1.198)\end{array}$ & $\begin{array}{c}-0.049 \\
(-0.927)\end{array}$ & $\begin{array}{c}0.117 \\
(0.850)\end{array}$ & $\begin{array}{c}0.089 \\
(0.666)\end{array}$ & $\begin{array}{c}-0.052 \\
(-0.972)\end{array}$ \\
\hline Retail Trade & $\begin{array}{c}0.306 * * * \\
(3.573)\end{array}$ & $\begin{array}{c}0.272 * * * * \\
(3.397)\end{array}$ & $\begin{array}{c}-0.031 \\
(-0.922)\end{array}$ & $\begin{array}{c}0.300^{* * * *} \\
(3.481)\end{array}$ & $\begin{array}{c}0.268 * * * \\
(3.303)\end{array}$ & $\begin{array}{c}-0.043 \\
(-1.292)\end{array}$ \\
\hline Finance & $\begin{array}{l}-0.052 \\
(-0.479)\end{array}$ & $\begin{array}{l}-0.020 \\
(-0.197)\end{array}$ & $\begin{array}{c}0.093 * * \\
(2.502)\end{array}$ & $\begin{array}{c}-0.018 \\
(-0.166)\end{array}$ & $\begin{array}{c}0.008 \\
(0.073)\end{array}$ & $\begin{array}{c}0.098^{* * * *} \\
(2.615)\end{array}$ \\
\hline Public Administration & $\begin{array}{c}0.341^{* * * *} \\
(5.975)\end{array}$ & $\begin{array}{c}0.264 * * * * \\
(4.749)\end{array}$ & $\begin{array}{c}-0.073 * * * * \\
(-3.652)\end{array}$ & $\begin{array}{c}0.324 * * * * \\
(5.655)\end{array}$ & $\begin{array}{c}0.260^{* * * *} \\
(4.660)\end{array}$ & $\begin{array}{c}-0.076^{* * * * *} \\
(-3.798)\end{array}$ \\
\hline Per Capita Crimes & $\begin{array}{c}0.102 \\
(1.117)\end{array}$ & $\begin{array}{c}0.062 \\
(0.703)\end{array}$ & $\begin{array}{c}-0.044 \\
(-1.452)\end{array}$ & $\begin{array}{c}0.050 \\
(0.549)\end{array}$ & $\begin{array}{c}0.022 \\
(0.241)\end{array}$ & $\begin{array}{c}-0.030 \\
(-0.968)\end{array}$ \\
\hline Per Capita Social Security Benefits & $\begin{array}{l}-0.019 \\
(-0.673)\end{array}$ & $\begin{array}{l}-0.021 \\
(-0.765)\end{array}$ & $\begin{array}{c}0.016 \\
(1.530)\end{array}$ & $\begin{array}{l}-0.019 \\
(-0.650)\end{array}$ & $\begin{array}{c}-0.019 \\
(-0.685)\end{array}$ & $\begin{array}{l}0.020^{*} \\
(1.904)\end{array}$ \\
\hline Per Capita Local Gov't Expenditures & $\begin{array}{l}-0.002^{* * *} \\
(-2.005)\end{array}$ & $\begin{array}{l}-0.002^{*} \\
(-1.646)\end{array}$ & $\begin{array}{c}0.000 \\
(-0.876)\end{array}$ & $\begin{array}{c}-0.003^{* * *} \\
(-2.107)\end{array}$ & $\begin{array}{l}-0.002^{*} \\
(-1.777)\end{array}$ & $\begin{array}{c}-0.001 \\
(-0.960)\end{array}$ \\
\hline Amenity Score & $\begin{array}{c}0.007 * * * \\
(4.395)\end{array}$ & $\begin{array}{c}0.005 * * * \\
(3.309)\end{array}$ & $\begin{array}{c}-0.002 * * * * \\
(-4.769)\end{array}$ & $\begin{array}{c}0.005 * * * \\
(2.907)\end{array}$ & $\begin{array}{c}0.004 * * \\
(2.325)\end{array}$ & $\begin{array}{c}-0.002 * * * * \\
(-3.541)\end{array}$ \\
\hline Rural Dummy & $\begin{array}{l}-0.001 \\
(-0.209)\end{array}$ & $\begin{array}{c}0.000 \\
(-0.089)\end{array}$ & $\begin{array}{c}0.004 * * \\
(2.484)\end{array}$ & $\begin{array}{l}-0.001 \\
(-0.232)\end{array}$ & $\begin{array}{c}0.000 \\
(-0.084)\end{array}$ & $\begin{array}{c}0.004 * * * * \\
(2.727)\end{array}$ \\
\hline Broadband Dummy & $\begin{array}{c}0.001 \\
(0.181)\end{array}$ & $\begin{array}{c}0.000 \\
(0.113)\end{array}$ & $\begin{array}{c}0.001 \\
(0.411)\end{array}$ & $\begin{array}{c}0.002 \\
(0.551)\end{array}$ & $\begin{array}{c}0.002 \\
(0.477)\end{array}$ & $\begin{array}{c}0.001 \\
(0.638)\end{array}$ \\
\hline$\rho$ (spatial lag parameter $)$ & & $\begin{array}{l}0.262^{* * * * *} \\
(10.657)\end{array}$ & $\begin{array}{l}1.199^{* * * *} \\
(116.960)\end{array}$ & & $\begin{array}{l}0.233 * * * * \\
(35.309)\end{array}$ & $\begin{array}{l}1.201 \text { **** } \\
(115.253)\end{array}$ \\
\hline$\lambda$ (spatial error parameter) & & & $\begin{array}{l}-2.299 * * * \\
(-82.147)\end{array}$ & & & $\begin{array}{l}-2.306 * * * * \\
(-82.612)\end{array}$ \\
\hline Constant & $\begin{array}{c}-0.110 \\
(-0.705)\end{array}$ & $\begin{array}{c}-0.101 \\
(-0.915)\end{array}$ & $\begin{array}{c}0.028 * * \\
(2.236) \\
\end{array}$ & $\begin{array}{c}0.062 \\
(0.392) \\
\end{array}$ & $\begin{array}{c}0.040^{* * * *} \\
(15.492)\end{array}$ & $\begin{array}{c}0.012 \\
(1.175) \\
\end{array}$ \\
\hline $\begin{array}{l}\text { Log Likelihood } \\
R^{2} \\
\text { Number of Observations }\end{array}$ & $\begin{array}{l}0.087 \\
2,987\end{array}$ & $\begin{array}{l}4,615.7 \\
0.095 \\
2,987\end{array}$ & $\begin{array}{l}5,023.6 \\
0.583 \\
2,987\end{array}$ & $\begin{array}{l}0.071 \\
2,987\end{array}$ & $\begin{array}{c}4593.6 \\
0.077 \\
2,987\end{array}$ & $\begin{array}{l}, 994.4 \\
0.573 \\
2,987\end{array}$ \\
\hline
\end{tabular}


TABLE A2. Lagrange Multiplier Statistics

\begin{tabular}{lcccc}
\hline & \multicolumn{2}{c}{ Net Total Migration } & \multicolumn{2}{c}{ Net Domestic Migration } \\
\cline { 2 - 4 } Lagrange Multiplier Statistic & Statistic & $p$-value & \multicolumn{2}{c}{ Statistic } \\
\hline Lag Statistic for Spatial Correlation in Dependent Variable of OLS model & 107.173 & 0.000 & 88.486 & 0.000 \\
Error Statistic for Spatial Correlation in Residuals of OLS model & 77.425 & 0.000 & 64.667 & 0.000 \\
Error Statistic for Spatial Correlation in Residuals in Spatial Lag Model & 328.866 & 0.007 & 73.084 & 0.007 \\
\hline
\end{tabular}

